\title{
Human Factors "Ergonomics" in Hydrocarbon Facilities
}

\author{
Nirmal Surendran Menon \\ Associate Member, Institution of Mechanical Engineers (IMechE), Graduate Member, Engineers New Zealand
}

\begin{abstract}
Human Factors often called "ergonomics" ensures the interaction of people-to-people, people with facilities and people with systems in the work environment, which identifies factors that affect human performance, and it facilitates practical ways to help reduce incidents while improving productivity.
\end{abstract}

Keywords: Working environment, Equipment Identification, Equipment Access, Signage and Label, Evacuation and Escape, Dead Leg.

\section{Introduction}

This article focuses on identifying the minimum requirements for integrating "Ergonomics" principles into the selection of various devices or equipment by identifying the minimum requirements for the facility design with respect to factors such as ease of access and movement and enhancing the operability and maintainability of the equipment in a hydrocarbon facility. This article also focuses on the minimum requirements for working environment to ensure the comfort and enhance the effectiveness of operating and maintenance personnel working in the hydrocarbon facility. Finally, this article also throws light on identifying the minimum requirements for evacuation and escape from facilities.

\section{Equipment Identification}

Permanent unique identification tags for every equipment or valve, ensuring primary identification that can be read from normal walkways is mandatory in any operating facility. In order to access the equipment, proper identification of the equipment is very important. All major equipment in a facility should be labelled. Typical list of equipment in a facility are as below:

\begin{tabular}{|c|c|c|}
\hline \multicolumn{3}{|c|}{ Mechanical Equipment } \\
\hline Compressors & $\begin{array}{c}\text { GTGs-Gas Turbine } \\
\text { Generators }\end{array}$ & Pumps \\
\hline Control Air Components & Power Turbines & Safety Showers \\
\hline Coolers & HVAC Components & Scrubbers \\
\hline ESD Valves & HVAC Fans & Separators \\
\hline Filters & $\begin{array}{c}\text { Manual Alarm Call } \\
\text { Points }\end{array}$ & $\begin{array}{c}\text { Sewage Treatment } \\
\text { Unit }\end{array}$ \\
\hline $\begin{array}{c}\text { Fire Water Header } \\
\text { Components }\end{array}$ & Plumbing Test Tees & $\begin{array}{c}\text { Sprinkler Drain } \\
\text { Valves }\end{array}$ \\
\hline Generators & Plumbing Valves & $\begin{array}{c}\text { Sprinkler Test } \\
\text { Valves }\end{array}$ \\
\hline Heat Exchangers & Potable Water Systems & Tanks \\
\hline \multicolumn{2}{|c}{}
\end{tabular}

\begin{tabular}{|c|c|c|}
\hline \multicolumn{3}{|c|}{ Electrical Equipment } \\
\hline Control Junction Boxes & Infrared Detectors & Speaker Amplifiers \\
\hline Gas Detectors & Receptacles & Thermal Detectors \\
\hline Handset Stations & Smoke Detectors & Transformers \\
\hline HVAC Terminal Boxes & Speakers & \\
\hline
\end{tabular}

All labels should have a functional description in a humanreadable format. All regulatory signs and labels should use both human-readable text and symbols to convey the information.

\section{1) Access to equipment and moving around}

Ease of access to equipment and movement is to be ensured by designing the Corridors, Access Ways, Doors, Exits etc. in an ergonomic friendly way. A one-way corridor or access way should have a minimum of $2.5 \mathrm{ft}(760 \mathrm{~mm})$ and a twoway corridor or access way should have a minimum of $4.5 \mathrm{ft}$ $(1370 \mathrm{~mm})$. Refer to Fig. A-1. A minimum of two exits are to be provided in enclosed, staffed areas where fuel, chemicals, or other flammable materials are used. These should be doors hinged to swing to the outside or kick-out panels. In areas housing large pieces of equipment such as compressors, the exits should be located so that it is possible to exit from either side of the equipment. Minimum door dimension requirement may be followed as per Fig. A-2. It must be ensured that the doors are at least $5 \mathrm{ft}(1500 \mathrm{~mm})$ from corners, i.e. junctures between two corridors, or where a single corridor turns a corner as per Fig. A-2b

\section{2) Equipment Access for operability}

The hydrocarbon facilities have numerous equipment such as Compressors, Pumps, and Instruments such as local panels, Piping system and valves etc. Mechanical equipment such as pumps, compressors etc. are to be positioned on a raised platform with access from all sides to avoid having to maintain the equipment while crouching at floor level. Factors to consider in determining if placing a pump on a raised platform is practical to include the need to provide a rigid support structure for the equipment and the desire to keep equipment piping and valve at a reasonable height for operations and maintenance. For mobility around piping system and valves, ensure that gangways to the location of large valves in large diameter pipework are sufficiently wide to move the valves to and from the location- $1 \mathrm{ft}$ is normally required either side of equipment or trolley. Recommended Mounting Heights for Valve Hand wheelsis shown below in Fig. A-3. For mobility and workspace around the Local Instrument Locations, clearance is to be ensured above and below control valves and that, this is sufficient to include access by mobile equipment in order to facilitate maintenance tasks. Instruments are to be located such that they are visible from the normal work position without needing to stand on other items of equipment, components, pipework, cable trays, handrails, etc. Locate important displays, those requiring precise, frequent, or emergency use, in a primary viewing area and at a height of

\section{Volume 8 Issue 3, March 2019


between $4 \mathrm{ft}$ and $5 \mathrm{ft}$ above the standing surface as indicated on Fig. A-4.

\section{3) Equipment access for maintainability}

The equipment should be provided access by overhead crane, local permanent hoist, or lifting beam plus portable crane, forklift truck, or trolley. The design of equipment should be such that it can be sub-divided into smaller subunits to facilitate removal, repair, or replacement of the subunits. Lifting eyes are provided for equipment weighing more than $150 \mathrm{lbs}$ with a minimum of 4 inch of space around the eye. The lifting eyes are to be correctly located with regard to the center of gravity of the item. Lifting limits on hoists, booms, and beams should be labelled and identified clearly along with lifting zones and laydown areas by use of floor markings.Adequate workspace should be available for the use and placement of tools, and for placing spare parts and components of equipment in the work area during their repair/replacement by taking into consideration the number of personnel required to do the work, equipment requirements (including maintenance instructions, check sheets, log books and other documentation that may be referred to), and body positions they may need to adopt. The type, size, and shape of access apertures chosen usually includes the consideration of the type of clothing and PPE that would be worn by the personnel. The workspace dimensions Based on American Society for Testing Materials (ASTM) 1988 is shown on Fig. A-5 and Table B1.

\section{Working Environment}

A good working environment in a facility is by ensuring adequate lighting, a good thermal environment, proper ventilation, adequate noise levels and excellent weather protection. Weather protection should also take into account protection factor that is required from adverse weather on personnel related to wind, rain, high temperature and humidity. Muster points should also have areas that give shelter from the elements related to adverse conditions mentioned above (wind, rain, high temperature and humidity).

\section{1) Evacuation and Escape}

An operating hydrocarbon facility normally has a Primary Evacuation route and a Secondary Evacuation route. The evacuation routes are provided as direct as possible avoiding frequent change in direction. In the event of changes in elevation (due to different deck levels), the evacuation is carried out via stairs or ramps. Ladders are only used at the rarest of rare events when stair or ramp is not available. The primary evacuation route passage widthshould be at least 5 ft (1525 millimeters) and should be maintained for the stairways, which is part of the evacuation route. Dead leg areas over 16 feet long are provided with at least two exits leading to evacuation routes. The emergency door and hatches during the emergency personnel movement is designed in such a way that the door open in the director of the moving personnel. These are designed in such a way that they are easily accessible, they are easy to operate even in dark, and they are quick open (opened by a maximum force of $30 \mathrm{lbs}$ ). Emergency doors and hatches are clearly marked on both sides of the door and hatch to prevent items being placed which will obstruct operation of the exit. Dimensions of escape hatches are large enough to accommodate personnel wearing heavy clothing, breathing apparatus, life jackets, etc. Minimum dimensions of hatches for sideways access through rectangular aperture in a vertical surface: Light clothing: $2.5 \mathrm{ft}$ high by $2.5 \mathrm{ft}$ wide, Bulky clothing: $2.5 \mathrm{ft}$ high by $3 \mathrm{ft}$ wide, for top and bottom access through a rectangular aperture in a horizontal surface: Light clothing: $2 \mathrm{ft}$ by $2.5 \mathrm{ft}$, Bulky clothing: $2.5 \mathrm{ft}$ by $3 \mathrm{ft}$, For circular apertures: Minimum diameter $=2.5 \mathrm{ft}$.

\section{Conclusion}

The Human Factors "Ergonomics" mainly focuses on the attributes such as "Moving to and Workspace around, Access, Visibility and Working positions, Manual Handling (laydown areas, lifting arrangement requirements etc.), Labelling, Status Identification (such as system alarms, beacons), Communication, Environmental Conditions among others to be implemented during the design and engineering of a facility in order to ensure smooth operations and maintenance of the facility post startup during its operations lifetime.

\section{References}

[1] Annual Book of ASTM Standards, copyright American Society of Testing and Materials, 100 Bar Harbor Drive, West Conshohock, PA 19428-2959

[2] ASME B31.3 Process Piping

[3] American Society for Testing Materials (ASTM) 1988

\section{Figures and Tables}


International Journal of Science and Research (IJSR)

ISSN: 2319-7064

Impact Factor (2018): 7.426

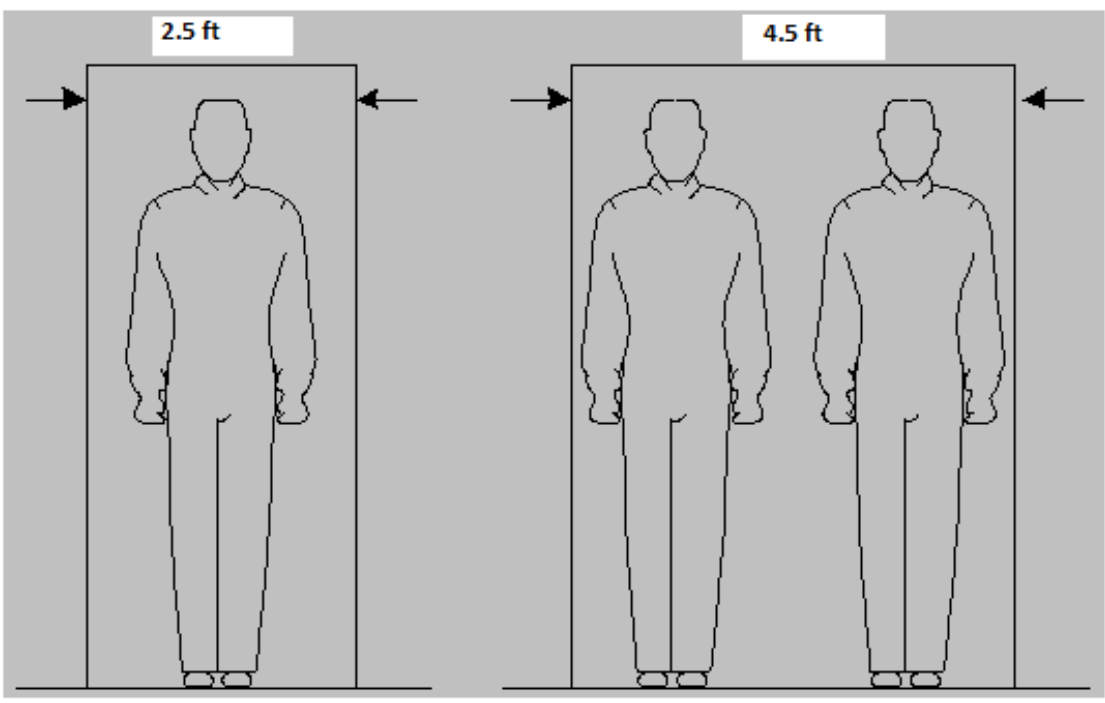

Figure A-1

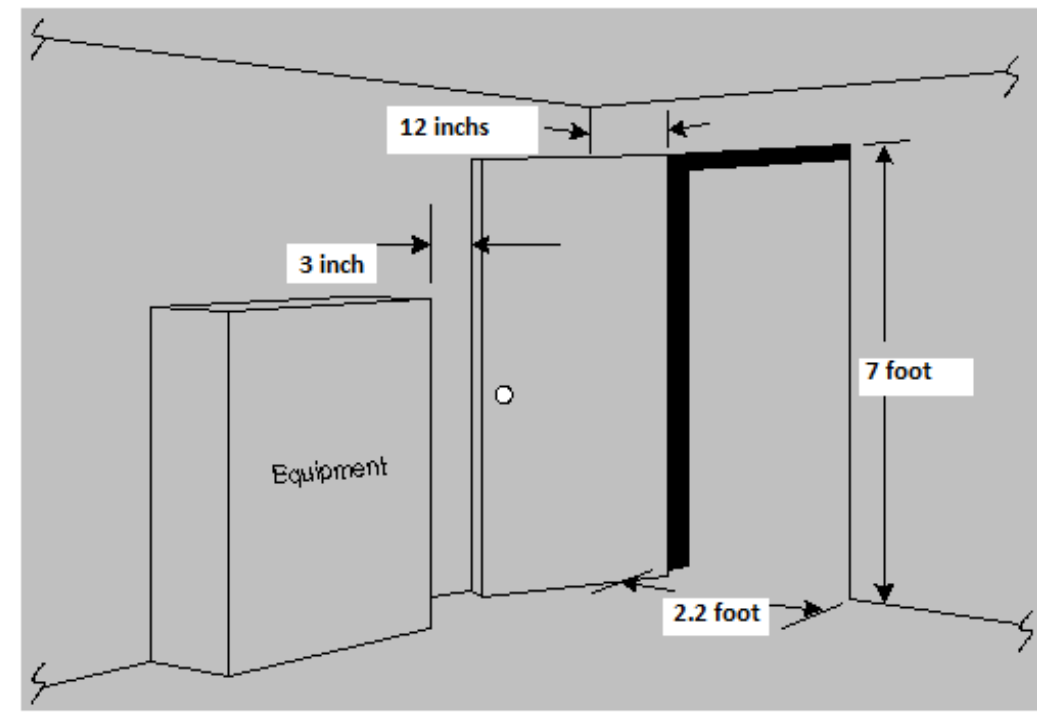

Figure A-2

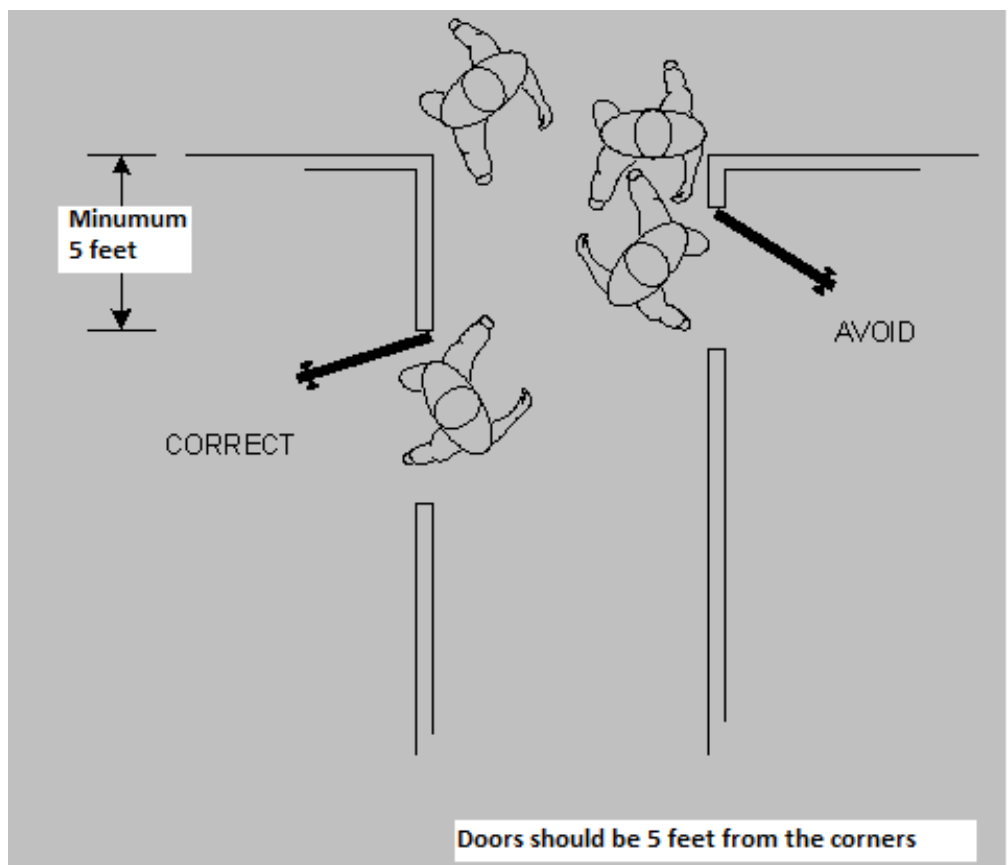

Figure A-2B

Volume 8 Issue 3, March 2019

www.ijsr.net

Licensed Under Creative Commons Attribution CC BY 
International Journal of Science and Research (IJSR)

ISSN: 2319-7064

Impact Factor (2018): 7.426

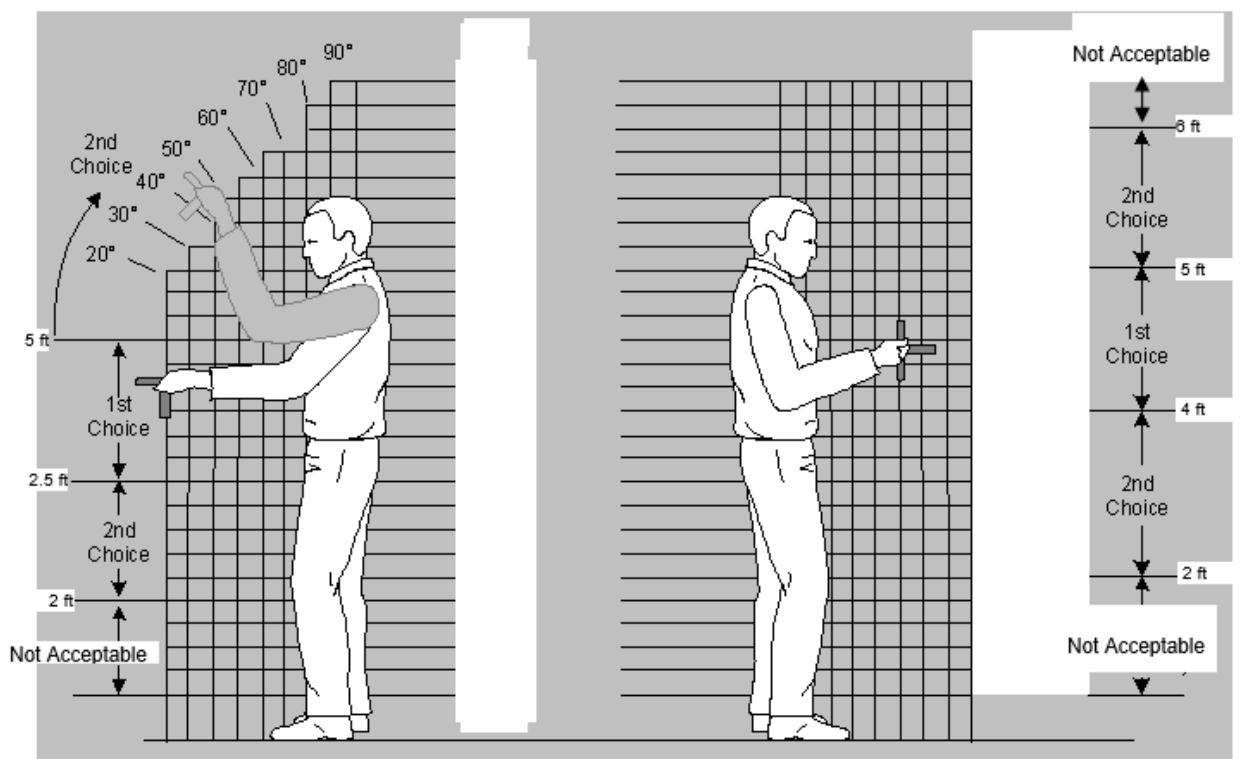

Figure A-3

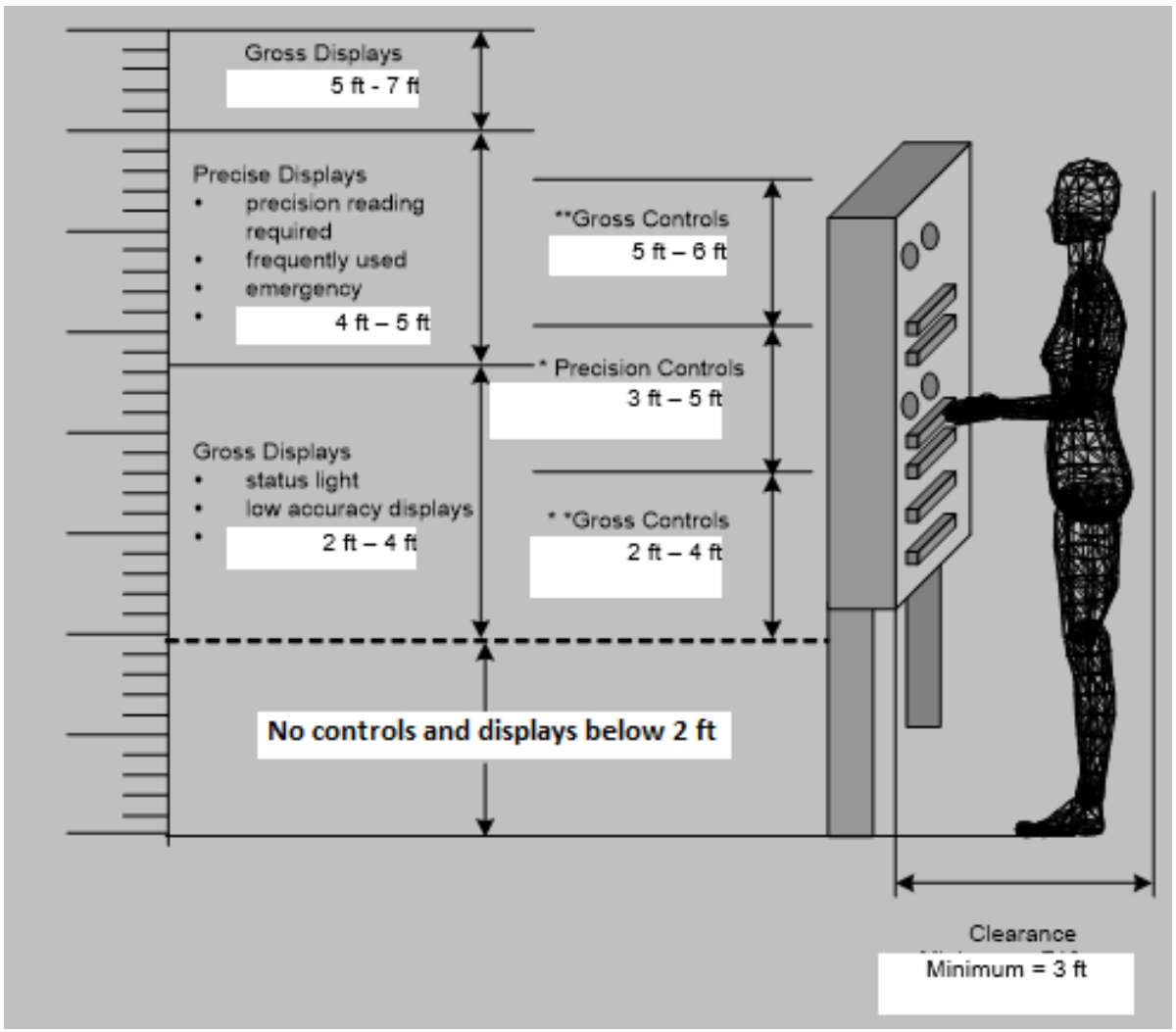

Figure A-4

Volume 8 Issue 3, March 2019

www.ijsr.net

Licensed Under Creative Commons Attribution CC BY 
International Journal of Science and Research (IJSR)

ISSN: 2319-7064

Impact Factor (2018): 7.426
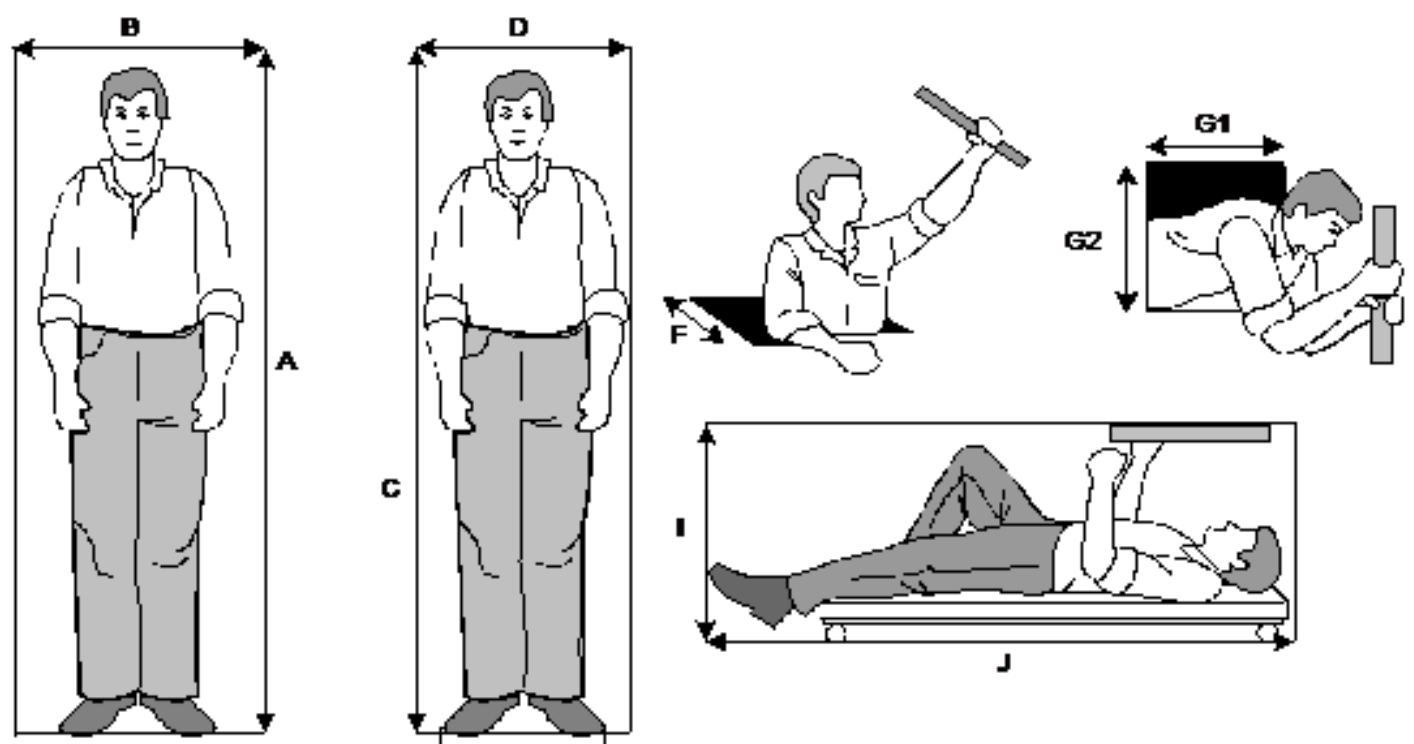

c
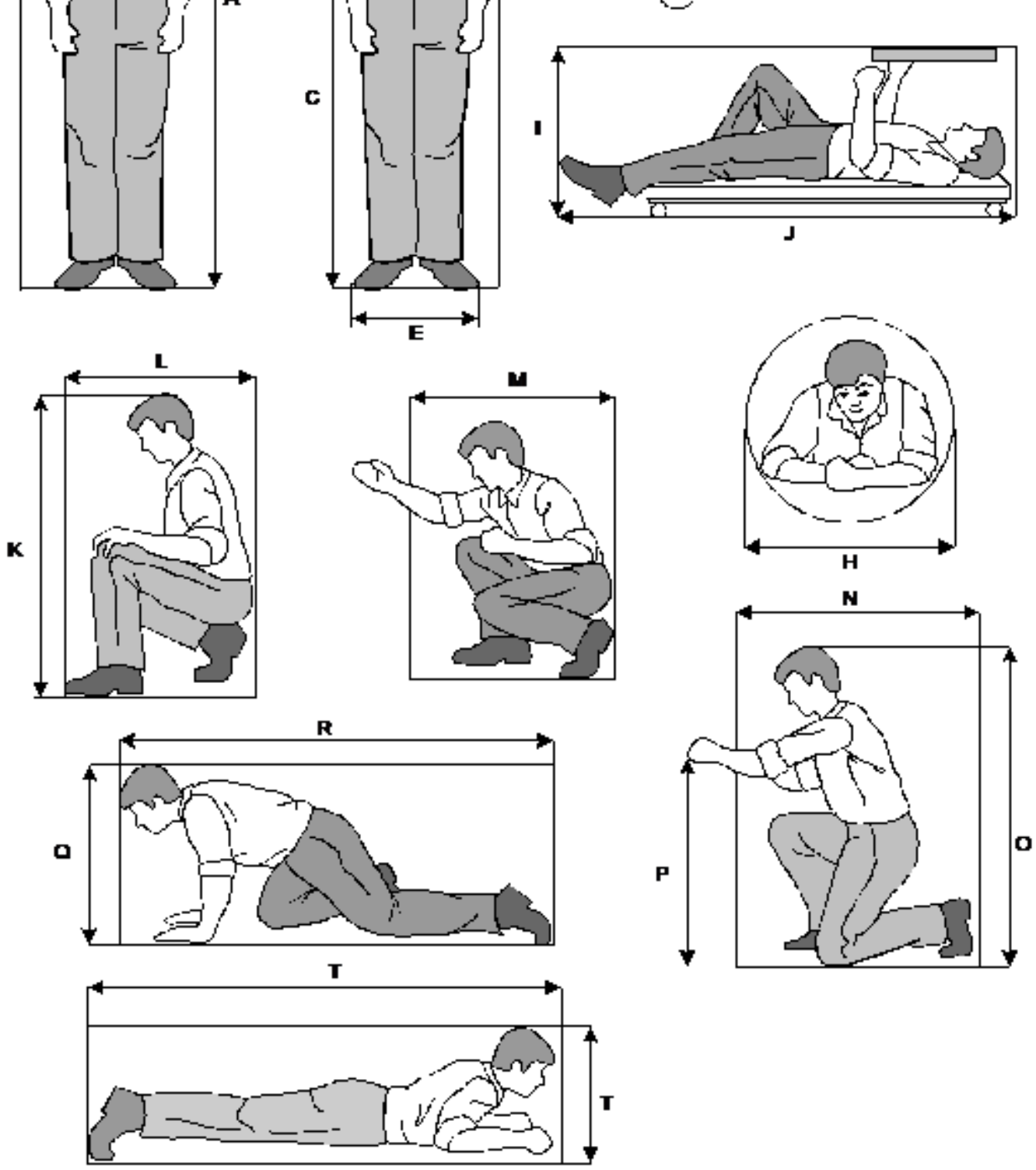

Figure A-5

Volume 8 Issue 3, March 2019 www.ijsr.net

Licensed Under Creative Commons Attribution CC BY 


\section{International Journal of Science and Research (IJSR)}

ISSN: 2319-7064

Impact Factor (2018): 7.426

Table B-1

\begin{tabular}{|l|l|}
\hline \multirow{2}{*}{ Workspace Area } & Minimum \\
\cline { 2 - 2 } & $\mathbf{f t}$ \\
\hline A. Height & 6.5 \\
\hline B. Width & 2.6 \\
\hline C. Height & 6.5 \\
\hline D. Shoulder width & 2 \\
\hline E. Walking width & 1.25 \\
\hline F. Square & 1.8 \\
\hline \multicolumn{1}{|c|}{ Round } & 2 \\
\hline G1. Shoulder Width & 2 \\
\hline \multicolumn{1}{|c|}{ Height } & 1.7 \\
\hline H. Round or square & 2.5 \\
\hline I. Height & 2 \\
\hline J. Length & 6.3 \\
\hline K. Height & 4 \\
\hline L. Depth & 3 \\
\hline M. Depth & 3.3 \\
\hline N. Depth & 4 \\
\hline O. Height & 4.5 \\
\hline P. Optimum Work Point & 2.25 \\
\hline Q. Height & 3 \\
\hline R. Length & 5 \\
\hline S. Height & 1.7 \\
\hline T. Length & 9.4 \\
\hline
\end{tabular}

Volume 8 Issue 3, March 2019

www.ijsr.net

Licensed Under Creative Commons Attribution CC BY 